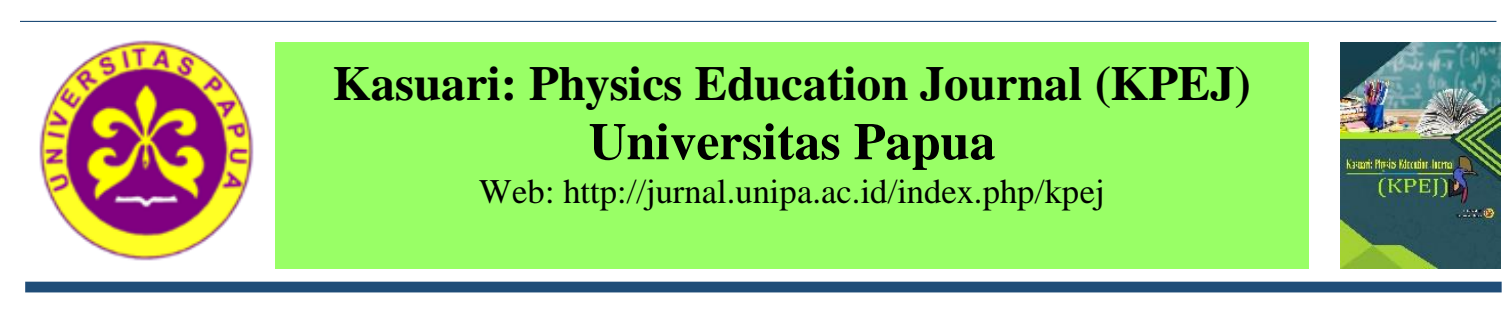

\title{
Analysis of Students' Critical Thinking Skills in Physics Problems
}

\author{
Tri Ariani \\ Program Studi Pendidikan Fisika, STKIP PGRI Lubuklinggau \\ Email: triariani.ta@gmail.com
}

\begin{abstract}
This study aims to determine the proportion of students' level of critical thinking skills on the subject of Impulse and Momentum, any difficulties experienced by students to reach the level of critical thinking skills, and solutions to overcome the difficulties of students achieving critical thinking skills. This research uses descriptive qualitative research methods. The subjects of this study were 27 students taken by purposive sampling technique. Data collection techniques in this study are tests of critical thinking skills, interviews, and observation. Data analysis techniques using descriptive statistics. The results showed that each student's ability, high ability students 36.84\%, medium ability $34.50 \%$, low ability $22.80 \%$ divided into two categories of KBK 2 with a percentage of $52.63 \%$ and KBK 1 with a percentage of 23, 94\%. From the results of the study also obtained the achievement of students every KBK indicator. Student achievement in the Interpretation indicator of $51.58 \%$ Analysis $18.75 \%$ Evaluation $13.87 \%$ Inference 31.48\% Explication $14.19 \%$ and Self Regulation 26.85\%. So KBK students as a whole are in the low category with a percentage of $31.38 \%$. The cause of students 'difficulties in fulfilling CBC indicators is the limited ability of students to formulate and find other alternatives, the completion of students' answers is difficult to draw conclusions and connect substance between materials, and has not been studied in depth so students tend to be careless in solving problems. The solution that can be used is to provide more experience to students in terms of critical thinking skills and additional learning outside school hours.
\end{abstract}

Keywords: Critical Thinking Skills, Impulses and Momentum

\section{Analisis Keterampilan Berpikir Kritis Siswa dalam Menyelesaikan Soal Fisika}

\begin{abstract}
Abstrak: Penelitian ini bertujuan untuk mengetahui proporsi tingkat keterampilan berpikir kritis siswa pada Pokok Bahasan Impuls dan Momentum, kesulitan apa saja yang dialami siswa untuk mencapai tingkat keterampilan berpikir kritis, dan solusi untuk mengatasi kesulitan siswa mencapai keterampilan berpikir kritis. Penelitian ini menggunakan metode penelitian deskriptif kualitatif. Subjek penelitian ini sebanyak 27 siswa diambil dengan teknik purposive sampling. Teknik pengumpulan data dalam penelitian ini yaitu tes keterampilan berpikir kritis, wawancara, dan observasi. Teknik analisis data menggunakan statistik deskriptif. Hasil penelitian menunjukan bahwa masing-masing kemampuan siswa, siswa berkemampuan tinggi 36,84\%, kemampuan sedang 34,50\%, kemampuan rendah 22,80\% terbagi manjadi dua kategori KBK 2 dengan persentase 52,63\% dan KBK 1 dengan persentase 23,94\%. Dari hasil penelitian didapatkan juga pencapaian siswa setiap indikator KBK. Pencapaian siswa dalam indikator Interpretasi sebesar 51,58\% Analisis 18,75\% Evaluasi 13,87\% Inferensi 31,48\% Eksplikasi 14,19\% dan Regulasi Diri 26,85\%. Sehingga KBK siswa secara keseluruhan berada pada kategori rendah dengan presentase $31,38 \%$. Penyebab kesulitan siswa dalam memenuhi indikator-indikator KBK adalah terbatasnya kemampuan siswa untuk merumuskan dan menemukan alternatif lain ,penyelesaian jawaban siswa sulit untuk menarik kesimpulan dan menghubungkan substansi antar materi, dan belum dipelajari secara mendalam sehingga siswa cenderung asal-asalan dalam menyelesaikan soal. Solusi yang dapat digunakan yaitu dengan memberikan pengalaman yang lebih kepada siswa dalam hal keterampilan berpikir kritis dan belajar tambahan diluar jam sekolah.
\end{abstract}

Kata kunci: Keterampilan Berpikir Kritis, Impuls dan Momentum 


\section{PENDAHULUAN}

Undang-Undang Nomor 20 Tahun 2003 tentang Sistem Pendidikan Nasional, Pasal 1 No. 1 menyatakan bahwa pendidikan adalah usaha sadar dan terencana untuk mewujudkan suasana belajar dan proses pembelajaran agar peserta didik secara aktif mengembangkan potensi dirinya untuk memiliki kekuatan spiritual keagamaan, pengendalian diri, kepribadian, kecerdasan, akhlak mulia, serta keterampilan yang diperlukan dirinya, masyarakat, bangsa dan negara. Salah satu keterampilan yang diperlukan mahasiswa terhadap dirinya, masyarakat, bangsa dan negara adalah keterampilan berpikir tingkat tinggi (Widyaningsih \& Yusuf, 2018). Kemampuan berpikir tingkat tinggi perlu dilatihkan kepada peserta didik agar mampu menyelesaikan berbagai persoalan yang dihadapi. Salah satu kemampuan berpikir tingkat tinggi yaitu kemampuan berpikir kritis. Kemampuan berpikir kritis adalah satu dari bagian penting dalam segala aspek kehidupan seseorang. Dalam kehidupan sehari-hari, tentu tidak pernah lepas dari masalah yang menuntut untuk berpikir kritis.

Fisika merupakan ilmu universal yang mendasari perkembangan teknologi modern dan mempunyai peran penting dalam berbagai disiplin ilmu dan memajukan daya pikir manusia. Perkembangan pesat di bidang teknologi informasi dan komunikasi dewasa ini di landasi oleh perkembangan fisika, untuk menguasai dan mencipta teknologi di masa depan di perlukan penguasaan konsep-konsep fisika yang kuat sejak dini. Oleh karena itu fisika berperan mempersiapkan siswa agar dapat menghadapi tantangan-tantangan di kehidupan yang semakin berkembang. Persiapan-persiapan tersebut dilakukan dengan membekali siswa kemampuan berpikir logis, analitis, sistematis, kritis dan kreatif serta kemampuan bekerja sama dalam pemecahan masalah (Ariani, 2017). Tujuan pembelajaran fisika salah satunya adalah menerapkan apa yang dipelajari ke dalam kehidupan sehari-hari, sehingga siswa perlu dilatih berpikir kritis untuk menerapkan konsep fisika dalam menghadapi masalah pada kehidupan sehari-hari. Konsekuensi dari pemikiran bahwa kemampuan berpikir kritis penting dalam pembelajaran fisika adalah guru harus memberikan unsur rangsangan dengan membuat sistem evaluasi yang dapat membuka pola pikir siswa dari mengingat fakta menuju pola pikir yang kritis (Misbah, Mahtari, Wati, \& Harto, 2018).

Pembelajaran di sekolah guru terbiasa memberikan contoh soal terlebih dahulu sebelum memberikan tes kepada siswa sehingga siswa akan kesulitan jika diberikan soal dengan bentuk yang berbeda. Selain itu juga keaktifan siswa yang masih rendah, dimana banyak yang beranggapan bahwa mata pelajaran fisika adalah suatu pelajaran yang sulit dan membosankan. Penyebabnya siswa kesulitan dalam perhitungan dan penghapalan rumus serta merasa sulit dan kurang percaya diri untuk mengungkapkan ide. Disamping itu juga siswa cenderung kurang memahami dalam memecahkan masalah. Kegiatan pembelajaran merupakan aktivitas guru untuk menciptakan kondisi yang memungkinkan proses belajar siswa berlangsung. Dalam prosesnya kegiatan pembelajaran dilakukan untuk menjadikan siswa dapat termotivasi untuk melakukan kegiatan berpikir dalam memahami dan menggali konsep untuk mencapai tujuan pembelajaran. Dengan demikian diperlukan peran guru dalam menentukan metode yang tepat yang dapat meningkatkan hasil belajar dan keterampilan siswa. Seorang pendidik harus bisa mengarahkan dan menggali potensi yang ada pada diri siswa, sehingga siswa mampu mengembangkan keterampilan-keterampilan tertentu di antaranya kemampuan berpikir kritis (Yati, 2015).

Penguasaan materi oleh siswa dapat ditunjukkan melalui proses berpikirnya. Proses berpikir merupakan salah satu kegiatan yang penting dalam pembelajaran. Ritdamaya (2015) keterampilan berpikir kritis bukanlah keterampilan bawaan sejak lahir sehingga keterampilan ini dapat diterapkan, dilatih dan dikembangkan melalui proses dan asesmen 
pembelajaran. Dalam proses pembelajaran guru sebagai mediator dan fasilitator mendesain dan menerapkan pendekatan, model atau strategi yang dapat memfasilitasi dan meningkatkan keterampilan berpikir kritis siswa. (Yati, 2015) menyatakan bahwa "Siswa SMA merupakan remaja yang perlu diperhatikan proses berpikirnya". Siswa SMA termasuk ke dalam usia tahap pemikiran operasional. Sedangkan Desmita (2012) menyatakan secara umum karakteristik pemikiran remaja pada tahap ini adalah diperolehnya kemampuan untuk berpikir secara abstrak, menalar secara logis, dan menarik kesimpulan dari informasi yang tersedia. Remaja di tahap operasional mampu memecahkan masalah dengan membuat perencanaan kegiatan terlebih dahulu dan berusaha mengantisipasi berbagai macam informasi yang akan diperluhkan untuk memecahkan masalah.

Berpikir kritis merupakan suatu proses kemampuan seseorang yang berguna untuk merumuskan jawaban atau mencari solusi dalam memecahkan suatu masalah. Keterampilan berpikir kritis merupakan salah satu kompetensi pembelajaran fisika dalam pendekatan saintifik. Artinya baik proses maupun asesmen pembelajaran fisika harus berorientasi untuk menumbuhkan dan membentuk keterampilan berpikir kritis siswa. (Ritdamaya, 2015) berpikir kritis adalah penalaran dan berpikir reflektif yang difokuskan untuk memutuskan apa yang diyakini dan dilakukan. Istilah keterampilan berpikir kritis mengacu pada kemampuan khusus yang diperoleh melalui pengalaman atau latihan untuk melakukan tugas tertentu secara baik, keterampilan berpikir kritis inipun menekankan pada kinerja aktual dalam melaksanakan tugas.

Berdasarkan hasil observasi awal yang dilakukan oleh peneliti di SMA Negeri 1 Muara Beliti didapatkan bahwa proses pembelajaran fisika masih menggunakan metode mengajar yang guru lebih mendominasi saat proses kegiatan belajar mengajar. Pembelajaran fisika di SMA umumnya dilakukan oleh guru lebih banyak menekan pada aspek pengetahuan, pemahaman, dan penerapan contohnya apa yang di maksud dengan Impuls dan Momentum? sedangkan aspek aplikasi, analisis, sintesis dan bahkan evaluasi hanya sebagian kecil pembelajaran yang dilakukan hal ini dilihat berdasarkan pada soalsoal yang diberikan tidak jauh berbeda dari contoh soal sebelumnya hanya angkaangkanya yang berbeda menyebabkan siswa kurang mengembangkan daya nalarnya dalam memecahkan masalah dan mengaplikasikan konsep-konsep yang telah dipelajari dalam kehidupan nyata. Sikap peserta didik yang menerima apa yang diberikan oleh guru dan siswa kurang antusias dalam mengikuti saat pembelajaran berlangsung menyebabkan tidak teraktifkannya potensi kemampuan siswa sehingga kurang terampil dalam berkomunikasi dalam kegiatan belajar mengajar didalam kelas. Sebagian siswa tidak memperhatikan ketika guru mengajar, dan dalam menyelesaikan tugas (PR) siswa masih banyak yang mencontek dilihat berdasarkan buku latihan siswa sebagian besar hanya satu jawaban dengan jalan penyelesaian hampir sama. Menurut mereka fisika itu sulit sehingga siswa tidak tertarik pada pelajaran fisika, dalam penyelesaian soal siswa masih terbiasa menggunakan penyelesaian masalah yang sama seperti apa yang telah diberikan oleh gurunya sehingga pola pikir siswa hanya terpaku pada satu penyelesaian saja tanpa mencoba, menganalisis dan menemukan cara yang baru. Selain itu, siswa juga mengalami kesulitan ketika soal yang diberikan sedikit berubah dari yang di contohkan oleh gurunya, dan masih kurangnya penggunaan media dalam proses belajar mengajar. Berdasarkan latar belakang yang diuraikan diatas tampak betapa pentingnya keterampilan berpikir kritis dalam penyelesaian masalah sehingga menghasilkan lulusan yang mampu berpikir kritis dan menjawab tantangan zaman. 


\section{LANDASAN TEORI}

\section{Keterampilan Berpikir Kritis}

Fisher (2008) mendefinisikan berpikir kritis adalah pertimbangan yang aktif, persistent (terus menerus), dan teliti mengenai sebuah keyakinan atau bentuk pengetahuan yang diterima begitu saja dipandang dari sudut alasan-alasan yang mendukungnya dan kesimpulan-kesimpulan lanjutan yang menjadi kecenderungannya. Berpikir kritis sebagai (a) suatu sikap mau berpikir secara mendalam tentang masalahmasalah dan hal-hal yang berada dalam jangkauan pengalaman seseorang. (b) pengetahuan tentang metode-metode pemeriksaan dan penalaran yang logis. (c) semacam suatu keterampilan untuk menerapkan metode-metode tersebut. Berpikir kritis menuntut upaya keras untuk memeriksa setiap keyakinan atau pengetahuan asumtif berdasarkan bukti pendukungnya dan kesimpulan-kesimpulan lanjutan yang diakibatkannya.

Lestari (2016) mendefinisikan bahwa berpikir kritis merupakan cara bagi seseorang untuk meningkatkan kualitas dari hasil pemikiran menggunakan teknik sistemasi cara berpikir dan menghasilkan daya pikir intelektual dalam ide-ide yang digagas. Seseorang yang berpikir secara kritis akan dapat menjawab permasalahan-permasalahan yang penting dengan baik. Dia akan berpikir secara jelas dan tepat. Selain itu dapat menggunakan ide yang abstrak untuk bisa membuat model penyelesaian masalah secara efektif.

Pada masa kini para ahli mengategorikan dua macam berpikir yang berbeda satu dengan yang lainnya yaitu berpikir dengan otak kiri dan otak kanan. Kedua kategori ini mempunyai karakteristik tersendiri dan berbeda dalam fungsinya. Berpikir dengan otak kiri lebih bersifat rasional, logis, kritis, analitis, dan memberikan timbangan (judgmental). Sementara berpikir dengan otak kanan mempunyai karakteristik abstrak, konseptual, kreatif, dan imajinatif. Berdasarkan pendapat diatas, dapat disimpulkan bahwa berpikir kritis adalah suatu keterampilan berpikir secara mendalam untuk merumuskan jawaban dan mencari solusi dalam memecahkan suatu masalah.

\section{Aspek-aspek Keterampilan Berpikir Kritis dalam fisika}

Ciri-ciri berpikir kritis adalah sebagai berikut: (1) Pandai mendeteksi permasalahan. (2) Mampu membedakan ide yang relevan dengan yang tidak relevan. (3) Mampu mengidentifikasikan perbedaan-perbedaan. (4) Dapat membedakan argumentasi logis dan tidak logis. (5) Mampu mengetes asumsi dengan cermat. (6) Mampu menarik kesimpulan generalisasi dari data yang telah tersedia dengan data yang diperoleh dari lapangan dan (7) Mampu menarik kesimpulan dari data yang telah ada dan terseleksi (Patmawati, 2011: 40). Selanjutnya Haryani (2012) bahwa seseorang yang mempunyai keterampilan berpikir kritis dapat di identifikasi dari perilaku yang diperlihatkannya. Adapun perilaku tersebut adalah sebagai berikut:

1. Keterampilan menganalisis

Keterampilan menganalisis merupakan suatu keterampilan yang menguraikan sebuah struktur ke dalam komponen-komponen agar mengetahui pengorganisasian struktur organisasi tersebut. Dalam keterampilan ini terkandung tujuan untuk memahami sebuah konsep dengan cara menguraikan atau merinci globalitas tersebut ke dalam bagian-bagian yang lebih kecil dan terperinci contohnya dari rumus gaya didapatkan bahwa percepatannya berbanding terbalik dengan massa benda. 
2. Keterampilan mensintesis

Keterampilan mensintesis merupakan keterampilan yang berlawanan dengan keterampilan menganalisis. Keterampilan mensintesis adalah keterampilan menggabungkan bagian-bagian menjadi sebuah bentukan atau susunan yang baru contohnya dari rumus gaya tadi dapat dicarikan rumus yang lainnya.

3. Keterampilan mengenal dan memecahkan masalah

Keterampilan ini merupakan keterampilan aplikatif konsep kepada beberapa pengertian. Keterampilan ini menuntut pembaca untuk memahami bacaan dengan kritis sehingga setelah selesai kegiatan membaca mampu menangkap beberapa pokok pikiran bacaan. Sehingga mampu mempola konsep. Pemecahan masalah mempunyai hubungan timbal balik dengan berpikir kritis. Melalui belajar memecahkan masalah dapat dibentuk antara lain cara berpikir secara analitik, logis, dan deduktif yang merupakan komponen berpikir kritis contohnya dengan komponen-komponen yang diketahui dapat dicari penyelesaian soalnya.

4. Keterampilan menyimpulkan

Keterampilan menyimpulkan adalah kegiatan akal pikiran manusia berdasarkan pengertian/pengetahuan (kebenaran) yang dimilikinya, dapat beranjak mencapai pengertian (kebenaran) yang baru lainnya contohnya kalau benda diam berarti kecepatannya sama dengan nol.

5. Keterampilan mengevaluasi atau menilai

Keterampilan ini menuntut pemikiran yang matang dalam menentukan nilai sesuatu dengan berbagai kriteria yang ada. Mampu membedakan informasi relevan dan tidak relevan serta mampu mengevaluasi pernyataan-pernyataan contohnya kita dapat menentukan penggunaan rumus secara tepat dari pemecahan masalah, berdasarkan apa saja yang diketahui.

Fithriyah (2016: 582) menerangkan bahwa indikator-indikator yang dapat digunakan dalam menginvestigasi kemampuan berpikir kritis salah satunya adalah indikator kemampuan berpikir kritis dari Facione, antara lain interpretasi (interpretation), analisis (analysis), evaluasi (evaluation), inferensi (inference), eksplikasi (explanation), dan regulasi diri (self-regulation).

a. Interpretasi adalah kemampuan yang dapat memahami dan mengekspresikan makna dari permasalahan.

b. Analisis adalah kemampuan yang dapat mengidentifikasi dan menyimpulkan hubungan dari pertanyaan, konsep, deskripsi, atau bentuk lainnya.

c. Evaluasi adalah kemampuan yang dapat mengakses kredibilitas pernyataan/representasi serta mampu mengakses secara logika hubungan antarpernyataan, deskripsi, maupun konsep.

d. Inferensi adalah kemampuan yang dapat mengidentifikasi dan mendapatkan unsurunsur yang dibutuhkan dalam menarik kesimpulan.

e. Eksplikasi adalah kemampuan dapat menetapkan dan memberikan alasan secara secara logis berdasarkan hasil yang diperoleh.

f. regulasi diri adalah kemampuan untuk memonitor aktifitas kognitif seseorang, unsurunsur yang digunakan dalam aktifitas menyelesaikan permasalahan, khususnya dalam menerapkan kemampuan dalam menganalisis dan mengevaluasi. Keenam indikator keterampilan berpikir kritis yang dikembangkan Facione diuraikan menjadi beberapa subskill seperti pada Tabel 1. 
Tabel 1. Indikator Keterampilan Berpikir Kritis Facione

\begin{tabular}{|c|c|c|}
\hline No. & $\begin{array}{l}\text { Aspek Keterampilan } \\
\text { Berpikir Kritis }\end{array}$ & Indikator \\
\hline \multirow[t]{3}{*}{1} & \multirow[t]{3}{*}{ Interpretasi } & $\begin{array}{l}\text { a. Dapat menggambarkan permasalahan yang } \\
\text { diberikan }\end{array}$ \\
\hline & & $\begin{array}{l}\text { b. Dapat menuliskan makna permasalahan dengan } \\
\text { jelas dan tepat }\end{array}$ \\
\hline & & $\begin{array}{l}\text { c. Dapat menuliskan apa yang diketahui dan } \\
\text { ditanyakan soal dengan tepat dan lengkap }\end{array}$ \\
\hline \multirow[t]{3}{*}{2} & \multirow[t]{3}{*}{ Analisis } & $\begin{array}{l}\text { a. Dapat menuliskan hubungan konsep-konsep yang } \\
\text { digunakan dalam menyelesaikan soal }\end{array}$ \\
\hline & & $\begin{array}{l}\text { b. Dapat menuliskan apa yang harus dilakukan dalam } \\
\text { menyelesaikan soal }\end{array}$ \\
\hline & & $\begin{array}{l}\text { c. Dapat membuat model matematis dari soal yang } \\
\text { diberikan dengan tepat dan lengkap }\end{array}$ \\
\hline \multirow[t]{2}{*}{3} & \multirow[t]{2}{*}{ Evaluasi } & $\begin{array}{l}\text { a. Dapat menuliskan penyelesaian soal secara tepat, } \\
\text { lengkap dan benar }\end{array}$ \\
\hline & & $\begin{array}{lcll}\text { b. Menggunakan strategi yang tepat } & \text { dalam } \\
\text { menyelesaikan soal, lengkap dan benar } & \text { dalam } \\
\text { melakukan perhitungan/penjelasan } & & \end{array}$ \\
\hline \multirow[t]{3}{*}{4} & \multirow[t]{3}{*}{ Inferensi } & $\begin{array}{l}\text { a. Dapat menarik kesimpulan dari apa yang ditanyakan } \\
\text { secara logis }\end{array}$ \\
\hline & & b. Dapat menduga alternatif lain \\
\hline & & $\begin{array}{l}\text { c. Dapat membuat kesimpulan dengan tepat sesuai } \\
\text { dengan konteks soal dan lengkap }\end{array}$ \\
\hline \multirow[t]{2}{*}{5} & \multirow[t]{2}{*}{ Eksplikasi } & $\begin{array}{l}\text { a. Dapat menuliskan hasil akhir dengan tepat dan } \\
\text { memberikan alasan tentang kesimpulan yang } \\
\text { diambil secara tepat dan benar }\end{array}$ \\
\hline & & $\begin{array}{l}\text { b. Dapat memberikan alasan tentang kesimpulan yang } \\
\text { diambil }\end{array}$ \\
\hline 6 & Regulasi Diri & $\begin{array}{l}\text { a. Dapat melakukan tinjauan ulang secara tepat } \\
\text { sesuai dengan konteks soal dan lengkap }\end{array}$ \\
\hline
\end{tabular}

(Fithriyah, 2016)

Dari keenam indikator keterampilan berpikir kritis yang dikemukakan Facione tersebut akan digunakan untuk mengetahui proporsi tingkatan keterampilan berpikir kritis siswa kelas X.MIA SMA Negeri 1 Muara Beliti, peneliti akan menganalisis aspek keterampilan berpikir kritis siswa pada setiap indikatornya pada materi Impuls dan Momentum. Indikator yang di gunakan dalam menganalisis keterampilan berpikir kritis dapat dilihat dari Tabel 2.

Tabel 2. Indikator yang digunakan dalam penelitian pada materi Impuls dan Momentum

\begin{tabular}{|c|c|c|}
\hline No. & $\begin{array}{c}\text { Aspek Keterampilan } \\
\text { Berpikir Kritis }\end{array}$ & \multicolumn{1}{c|}{ Indikator } \\
\hline 1 & Interpretasi & $\begin{array}{l}\text { Dapat menuliskan apa yang diketahui dan ditanyakan } \\
\text { soal dengan tepat dan lengkap pada konsep Impuls dan } \\
\text { Momentum, hubungan Impuls dan Momentum, dan } \\
\text { kekekalan momentum. }\end{array}$ \\
\hline
\end{tabular}




\begin{tabular}{|c|l|l|}
\hline No. & $\begin{array}{c}\text { Aspek Keterampilan } \\
\text { Berpikir Kritis }\end{array}$ & \multicolumn{1}{|c|}{ Indikator } \\
\hline 2 & Analisis & $\begin{array}{l}\text { Dapat membuat model matematis dari soal yang } \\
\text { diberikan dengan tepat dan lengkap pada konsep } \\
\text { Impuls dan Momentum, hubungan Impuls dan } \\
\text { Momentum, dan kekekalan momentum. }\end{array}$ \\
\hline 3 & Evaluasi & $\begin{array}{l}\text { Dapat menggunakan strategi yang tepat dalam } \\
\text { menyelesaikan soal, lengkap dan benar dalam } \\
\text { melakukan perhitungan/penjelasan pada konsep Impuls } \\
\text { dan Momentum, hubungan Impuls dan Momentum, } \\
\text { dan kekekalan momentum. }\end{array}$ \\
\hline 4 & Inferensi & $\begin{array}{l}\text { Dapat membuat kesimpulan dengan tepat sesuai } \\
\text { dengan konteks soal dan lengkap pada konsep Impuls } \\
\text { dan Momentum, hubungan Impuls dan Momentum, } \\
\text { dan kekekalan momentum. }\end{array}$ \\
\hline 5 & Eksplikasi & $\begin{array}{l}\text { Dapat menuliskan hasil akhir dengan tepat dan } \\
\text { memberikan alasan tentang kesimpulan yang diambil } \\
\text { secara tepat dan benar pada konsep Impuls dan } \\
\text { Momentum, hubungan Impuls dan Momentum, dan } \\
\text { kekekalan momentum. }\end{array}$ \\
\hline 6 & Regulasi Diri & $\begin{array}{l}\text { Dapat melakukan tinjauan ulang secara tepat sesuai } \\
\text { dengan konteks soal dan lengkap pada konsep Impuls } \\
\text { dan Momentum, hubungan Impuls dan Momentum, } \\
\text { dan kekekalan momentum. }\end{array}$ \\
\hline
\end{tabular}

Sumber : (Modifikasi Facione dalam Fithriyah, 2016)

\section{Tingkatan Keterampilan Berpikir Kritis}

Ada enam tingkatan berpikir kritis yaitu:

1. Berpikir yang tidak direfleksikan (unreflective thinking)

Pemikir tidak menyadari peran berpikir dalam kehidupan, kurang mampu menilai pemikirannya, dan mengembangkan beragam kemampuan berpikir tanpa menyadarinya. Akibatnya gagal menghargai berpikir sebagai aktivitas yang melibatkan elemen bernalar. Mereka tidak menyadari standar yang tepat untuk penilaian berpikir yaitu kejelasan, ketepatan, ketelitian, relevansi, dan kelogisan.

2. Berpikir yang menantang (challenged thinking)

Pemikir sadar peran berpikir dalam kehidupan, menyadari berpikir berkualitas membutuhkan berpikir reflektif yang disengaja, dan menyadari berpikir yang dilakukan sering kekurangan tetapi tidak dapat mengidentifikasikan dimana kekurangannya. Pemikir pada tingkat ini memiliki kemampuan berpikir yang terbatas.

3. Berpikir permulaan (beginning thinking)

Pemikir mulai memodifikasi beberapa kemampuan berpikirnya tetapi memiliki perencanaan yang sistematis untuk meningkatkan kemampuan berpikirnya.

4. Berpikir latihan (practicing thinking)

Pemikir menganalisis pemikirannya secara aktif dalam sejumlah bidang namun mereka masih mempunyai wawasan terbatas dalam tingkatan berpikir yang mendalam. 
5. Berpikir lanjut (advanced thinking)

Memiliki pengetahuan yang penting tentang masalah pada tingkatan berpikir yang mendalam, namun mereka belum mampu berpikir pada tingkat yang lebih tinggi secara konsisten pada semua dimensi kehidupannya.

6. Berpikir yang unggul (accomplished thinking)

Pemikir menginternalisasikan kemampuan dasar berpikir secara mendalam, berpikir kritis dilakukan secara sadar dan menggunakan intuisi yang tinggi. Mereka menilai pikiran secara kejelasan, ketepatan, relevansi, dan kelogisan ( Fatmawati, 2014). Selanjutnya untuk menentukan tingkat keterampilan berpikir kritis siswa dalam penelitian ini ada 4 (empat) tingkatan yang digunakan, yaitu dalam Tabel 3.

Tabel 3. Tingkatan Berpikir Kritis

\begin{tabular}{|l|l|}
\hline \multicolumn{1}{|c|}{ Tingkatan Berpikir Kritis } & \multicolumn{1}{c|}{ Deskripsi } \\
\hline $\begin{array}{l}\text { Tingkat Keterampilan Berpikir Kritis 1 } \\
\text { (KBK 1) }\end{array}$ & $\begin{array}{l}\text { Yaitu jawaban siswa yang sesuai dengan } \\
\text { satu atau dua indikator berpikir kritis }\end{array}$ \\
\hline $\begin{array}{l}\text { Tingkat Keterampilan Berpikir Kritis 2 } \\
\text { (KBK 2) }\end{array}$ & $\begin{array}{l}\text { Yaitu jawaban siswa sesuai dengan dua atau } \\
\text { tiga indikator }\end{array}$ \\
\hline $\begin{array}{l}\text { Tingkat Keterampilan Berpikir Kritis 3 } \\
\text { (KBK 3) }\end{array}$ & $\begin{array}{l}\text { Yaitu jawaban siswa sesuai dengan tiga atau } \\
\text { empat indikator berpikir kritis }\end{array}$ \\
\hline $\begin{array}{l}\text { Tingkat Keterampilan Berpikir Kritis 4 } \\
\text { (KBK 4) }\end{array}$ & $\begin{array}{l}\text { Yaitu jawaban siswa sesuai dengan lima atau } \\
\text { enam indikator berpikir kritis }\end{array}$ \\
\hline
\end{tabular}

Sumber : (Modifikasi Siswono dalam Fatmawati, 2014: 912-913)

\section{Upaya-Upaya Dalam Meningkatkan Keterampilan Berpikir Kritis Siswa}

Susanto (dalam Karim, 2015) menyatakan bahwa upaya untuk pembentukan keterampilan berpikir kritis siswa yang optimal adalah (1) Adanya kelas yang interaktif. (2) Siswa dipandang sebagai pemikir bukan seorang yang diajar. (3) Pengajar berperan sebagai mediator, fasilitator, dan motivator yang membantu siswa dalam belajar bukan pengajar. (4) Keahlian dalam memilih dan menggunakan model pembelajaran yang tepat. Selanjutnya Eggen dan Kauchak (dalam Patmawati, 2011:9) menjelaskan bahwa ada enam ciri pembelajaran yang efektif yang dapat menumbuhkan keterampilan berpikir kritis siswa yaitu: (1) siswa menjadi pengkaji yang aktif terhadap lingkungannya melalui mengobservasi, membandingkan, menemukan kesamaan-kesamaan dan perbedaanperbedaan serta membentuk konsep dan generalisasi berdasarkan kesamaan-kesamaan yang ditemukan. (2) guru menyediakan materi sebagai fokus berpikir dan berinteraksi dalam pelajaran. (3) aktivitas-aktivitas siswa sepenuhnya didasarkan pada pengkajian. (4) guru secara aktif terlibat dalam pemberian arahan dan tuntunan kepada siswa dalam menganalisis informasi. (5) orientasi pembelajaran penguasaan isi pelajaran dan pengembangan keterampilan berpikir, dan (6) guru menggunakan teknik mengajar yang bervariasi sesuai dengan tujuan dan gaya mengajar guru.

\section{METODE PENELITIAN}

Jenis penelitian ini adalah penelitian deskriptif dengan menggunakan metode kualitatif. Sukmadinata (2015) menyatakan penelitian kualitatif adalah penelitian yang ditujukan untuk mendeskripsikan dan menganalisis fenomena-fenomena, peristiwa, dan aktifitas sosial secara alamiah. Arikunto (2013) menyatakan bahwa penelitian deskriptif tidak dimaksudkan untuk menguji hipotesis tertentu, tetapi menggambarkan tentang 
suatu variabel tanpa memberikan perlakuan. Hal ini sesuai dengan Sukmadinata (2015) yang mendefinisikan penelitian deskriptif adalah penelitian yang diarahkan untuk memperoleh gambaran tentang keadaan pada saat penelitian berlangsung. Untuk mendiagnosis kemampuan berpikir kritis subjek penelitian, Peneliti menggunakan instrumen berupa soal tes uraian yang diambil dari soal Ujian Nasional (UN) 2007 s.d 2016. Skor jawaban tes dari setiap tahap akan dikaji untuk menentukan seberapa besar indikator-indikator kemampuan berpikir kritis yang dicapai oleh subjek penelitian. Kemudian peneliti mengkonversikan skor yang diperoleh oleh setiap subjek penelitian menjadi nilai untuk menentukan kategori kemampuan berpikir kritisnya. Setelah itu peneliti dapat menghitung persentase kemampuan berpikir kritis dari kategori rendah, sedang, tinggi, hingga pada kategori sangat tinggi. Kemudian peneliti melakukan observasi untuk melihat dan mencatat langsung keterampilan berpikir kritis siswa pada saat proses belajar mengajar dilaksanakan. Dari kegiatan observasi ini, harapannya peneliti dapat mendiagnosis lebih dalam kemampuan berpikir siswa serta dapat menentukan solusi yang tepat dalam meningkatkan kemampuan berpikir kritis siswa. Untuk mengetahui lebih lanjut kemampuan berpikir kritis siswa dan mengetahui kesulitan siswa dalam mencapai indikator berpikir kritis, maka dilakukan wawancara kepada beberapa siswa yang mewakili setiap kategori kemampuan berpikir kritisnya.

Pada penelitian ini teknik pengumpulan data dilakukan dengan cara triangulasi teknik dan triangulasi sumber. Triangulasi teknik yaitu triangulasi dengan sumber yang sama tetapi dengan cara atau metode yang berbeda, triangulasi sumber berarti untuk mendapatkan data dari sumber yang berbeda dengan teknik yang sama. Arikunto (2010) dalam penelitian apapun sebenarnya prinsip triangulasi sangat penting adanya yaitu tri artinya tiga, angulasi dari kata angle yang artinya sudut. Jadi triangulasi adalah teknik pengumpulan data dengan menggabungkan beberapa teknik atau sumber yang berbeda sehingga fenomena yang dikaji semakin jelas. Triangulasi yang digunakan dalam penelitian ini adalah dengan cara triangulasi teknik dan triangulasi sumber. Triangulasi teknik yaitu dengan sumber yang sama tetapi dengan teknik atau metode yang berbeda. Adapun teknik pengumpulan data pada penelitian ini adalah dokumentasi hasil tes diagnosis keterampilan berpikir kritis, wawancara dan observasi. Analisis data dalam penelitian kualitatif dilakukan pada saat pengumpulan data berlangsung, dan setelah selesai pengumpulan data dalam periode tertentu. Miles dan Huberman (dalam Sugiyono 2009) menjelaskan bahwa aktifitas dalam analisis data kualitatif dilakukan secara interaktif dan berlangsung secara terus menerus sampai tuntas. Tahapan aktifitas analisis data, yaitu data reduction, data display, dan conclusion drawing/verification. Teknik analisis data yang digunakan dalam penelitian ini adalah teknik analisis data deskriptif dengan menggunakan perhitungan persentase dengan langkah-langkah sebagai berikut:

1. Memeriksa lembar jawaban siswa sehingga didapatkan skor per indikator keterampilan berpikir kritis setiap siswa.

2. Menentukan pencapaian indikator keterampilan berpikir kritis yang diperoleh siswa berdasarkan pedoman penskoran holistik keterampilan berpikir kritis siswa.

3. Mengkonversikan skor perolehan masing-masing siswa menjadi nilai dengan rumus :

$$
\mathrm{NP}=\frac{S P}{S M} \times 100 \%
$$

Keterangan:

NP : Perolehan nilai persentase keterampilan berpikir kritis

SP : Skor yang diperoleh siswa

SM : Skor maksimum tes keterampilan berpikir kritis 
4. Menentukan kategori keterampilan berpikir kritis setiap siswa seperti sangat tinggi, tinggi, sedang, dan rendah. Untuk mengambil kesimpulan kategori keterampilan berpikir kritis subjek penelitian secara keseluruhan dalam penelitian ini, akan dicari persentase rata-rata keseluruhan subjek penelitian. Adapun pedoman dalam menentukan kategori keterampilan berpikir kritis siswa dijelaskan pada Tabel 4.

Tabel 4. Kategori Keterampilan Berpikir Kritis

\begin{tabular}{|c|c|}
\hline Persentase Pencapaian $(\%)$ & Kategori \\
\hline $81,25<\mathrm{KBK} \leq 100$ & Sangat Tinggi \\
\hline $62,50<\mathrm{KBK} \leq 81,25$ & Tinggi \\
\hline $43,75<\mathrm{KBK} \leq 62,50$ & Sedang \\
\hline $25<\mathrm{KBK} \leq 43,75$ & Rendah \\
\hline
\end{tabular}

Sumber : (Modifikasi Setyowati dalam Karim, 2015)

5. Mendiagnosis lebih dalam subjek penelitian dengan melakukan wawancara kepada siswa untuk setiap kategori keterampilan berpikir kritis.

6. Menetapkan kesimpulan dan menjawab rumusan masalah yang telah ditetapkan.

\section{HASIL DAN PEMBAHASAN}

Penelitian ini dilaksanakan di SMA Negeri 1 Muara Beliti dengan subjek penelitian kelas X.MIA yang berjumlah 27 siswa setiap kelasnya mewakili sembilan siswa yang masing-masing terdiri tiga berkemampuan tinggi, tiga berkemampuan sedang, dan tiga berkemampuan rendah berdasarkan nilai Ulangan Tengah Semester. Penelitian dilakukan dengan memberikan instrumen diagnosis Keterampilan Berpikir Kritis (KBK) berupa soal sebanyak sepuluh butir soal yang diambil dari soal Ujian Nasional (UN) sepuluh tahun terakhir dan sudah di validasi oleh dua dosen ahli. Setiap soal memuat satu sampai dengan tiga indikator KBK dari jumlah indikator yang digunakan sebanyak enam indikator, proses penelitian dengan menggunakan tiga macam teknik pengumpulan data secara bertahap dan sistematis.

Data hasil dokumentasi jawaban tes diagnosis KBK dianalisis dengan menghitung perolehan skor sesuai pedoman penskoran yang peneliti gunakan pada setiap indikator maupun secara keseluruhan. Setiap indikator memiliki skor maksimal 4 apabila jawaban siswa telah mencapai kriteria indikator yang diharapkan. Analisis keterampilan berpikir kritis yang dilakukan dalam penelitian ini menggunakan indikator keterampilan berpikir kritis Facione yaitu indikator interpretasi, analisis, evaluasi, inferensi, eksplikasi, dan regulasi diri. Adapun komposisi indikator KBK pada masing-masing butir soal dapat diperhatikan pada Tabel 5.

Tabel 5. Indikator KBK pada Instrumen yang Digunakan

\begin{tabular}{|c|l|c|c|}
\hline No. & \multicolumn{1}{|c|}{ Indikator KBK } & Nomor Soal & Skor Maksimal \\
\hline 1 & Interpretasi & $1,3,4,5,6,7$, dan 9 & 28 \\
\hline 2 & Analisis & $1,8,9$ dan 10 & 16 \\
\hline 3 & Evaluasi & 5, dan 8 & 8 \\
\hline 4 & Inferensi & 2 dan 7 & 8 \\
\hline 5 & Eksplikasi & 2,7, dan 10 & 12 \\
\hline 6 & Regulasi Diri & 2 & 4 \\
\hline \multicolumn{2}{r}{} \\
\hline
\end{tabular}


Pada indikator interpretasi ada tujuh butir soal dengan skor maksimal secara keseluruhan 28, indikator analisis ada empat butir soal dengan skor maksimal secara keseluruhan 16, indikator evaluasi ada dua butir soal dengan skor maksimal 8, indikator inferensi ada dua butir soal dengan skor maksimal 8, indikator eksplikasi ada tiga butir soal dengan skor maksimal 12, dan indikator regulasi diri ada satu butir soal dengan skor maksimal 4, dari skor maksimal masing-masing indikator tersebut dibagi empat kategori KBK, (KBK 1) rendah, (KBK 2) sedang, (KBK 3) tinggi, dan (KBK 4) sangat tinggi.

Setelah peneliti mengoreksi, menilai, dan merekap data hasil diagnosis KBK pada lembar observasi dokumen tes dignosis, selanjutnya peneliti mengkategorikan siswa berdasarkan hasil diagnosis KBK tersebut menjadi empat kategori atau kelompok yaitu kelompok keterampilan berpikir kritis sangat tinggi (KBK 4), kelompok keterampilan berpikir kritis tinggi (KBK 3), kelompok keterampilan berpikir kritis sedang (KBK 2), kelompok keterampilan berpikir kritis rendah (KBK 1). Perolehan skor dan pengelompokan siswa dari hasil diagnosis KBK ditampilkan pada Tabel 6, Tabel 7, dan Tabel 8.

Tabel 6 Rekapitulasi dan Kategori Tes Diagnosis KBK Siswa Kemampuan Tinggi

\begin{tabular}{|c|l|r|r|r|r|r|r|r|l|}
\hline \multirow{2}{*}{ No. } & \multirow{2}{*}{ Subjek } & \multicolumn{6}{|c|}{ Pencapaian KBK per Indikator $(\%)$} & \multirow{2}{*}{} \\
\cline { 3 - 8 } & & 1 & 2 & 3 & 4 & 5 & 6 & \multirow{2}{*}{ KBK (\%) } & \multirow{2}{*}{ Kelompok KBK } \\
\hline 1 & J & 71,43 & 31,25 & 37,50 & 87,50 & 41,67 & 75,00 & 56,58 & KBK 2 \\
\hline 2 & FH & 35,71 & 6,25 & 0,00 & 0,00 & 0,00 & 0,00 & 14,47 & KBK 1 \\
\hline 3 & SO & 85,71 & 12,50 & 12,50 & 50,00 & 16,67 & 50,00 & 46,05 & KBK 2 \\
\hline 4 & WNY & 64,28 & 37,50 & 37,50 & 50,00 & 25,00 & 50,00 & 47,37 & KBK 2 \\
\hline 5 & MG & 50,00 & 18,75 & 0,00 & 0,00 & 0,00 & 0,00 & 22,37 & KBK 1 \\
\hline 6 & NND & 100 & 31,25 & 0,00 & 62,50 & 16,67 & 25,00 & 53,94 & KBK 2 \\
\hline 7 & YS & 71,42 & 31,25 & 0,00 & 37,50 & 16,67 & 0,00 & 39,47 & KBK 1 \\
\hline 8 & NA & 57,14 & 25,00 & 0,00 & 0,00 & 0,00 & 0,00 & 26,31 & KBK 1 \\
\hline 9 & IA & 50,00 & 12,50 & 0,00 & 25,00 & 8,33 & 0,00 & 25,00 & KBK 1 \\
\hline
\end{tabular}

Tabel 7. Rekapitulasi dan Kategori Tes Diagnosis KBK Siswa Kemampuan Sedang

\begin{tabular}{|c|l|r|r|r|r|r|r|r|r|}
\hline \multirow{2}{*}{ No. } & \multirow{2}{*}{ Subjek } & \multicolumn{7}{|c|}{ Pencapaian KBK per Indikator $(\%)$} & \multirow{2}{*}{} \\
\cline { 3 - 8 } & & 1 & 2 & 3 & 4 & 5 & 6 & \multirow{2}{*}{ KBK (\%) } & \multirow{2}{*}{ Kelompok KBK } \\
\hline 10 & HDY & 39,28 & 18,75 & 0,00 & 0,00 & 0,00 & 0,00 & 18,42 & KBK 1 \\
\hline 11 & PYS & 32,14 & 6,25 & 0,00 & 0,00 & 0,00 & 0,00 & 13,16 & KBK 1 \\
\hline 12 & YY & 96,43 & 12,50 & 25,00 & 25,00 & 16,67 & 0,00 & 46,25 & KBK 2 \\
\hline 13 & SF & 57,14 & 12,50 & 0,00 & 37,50 & 8,33 & 0,00 & 28,94 & KBK 1 \\
\hline 14 & RA & 57,14 & 50,00 & 75,00 & 75,00 & 33,33 & 75,00 & 56,58 & KBK 2 \\
\hline 15 & A & 57,14 & 18,75 & 0,00 & 25,00 & 16,67 & 50,00 & 32,89 & KBK 1 \\
\hline 16 & Y & 82,14 & 50,00 & 50,00 & 50,00 & 50,00 & 50,00 & 61,84 & KBK 2 \\
\hline 17 & RR & 50,00 & 31,25 & 50,00 & 50,00 & 25,00 & 50,00 & 42,10 & KBK 1 \\
\hline 18 & SR & 21,43 & 0,00 & 0,00 & 25,00 & 0,00 & 0,00 & 10,53 & KBK 1 \\
\hline
\end{tabular}


Tabel 8. Rekapitulasi dan Kategori Tes Diagnosis KBK Siswa Kemampuan Rendah

\begin{tabular}{|l|l|c|c|c|c|c|c|c|c|}
\hline \multirow{2}{*}{ No. } & \multirow{2}{*}{ Subjek } & \multicolumn{7}{|c|}{ Pencapaian KBK per Indikator (\%) } & \multirow{2}{*}{} \\
\cline { 3 - 8 } & & 1 & 2 & 3 & 4 & 5 & 6 & \multirow{2}{*}{ KBK (\%) } & \multirow{2}{*}{ Kelompok KBK } \\
\hline 19 & DMJ & 14,28 & 0,00 & 0,00 & 37,50 & 25,00 & 50,00 & 15,79 & KBK 1 \\
\hline 20 & B & 35,71 & 12,50 & 0,00 & 25,00 & 8,33 & 50,00 & 22,37 & KBK 1 \\
\hline 21 & TH & 53,57 & 12,50 & 12,50 & 25,00 & 8,33 & 50,00 & 30,26 & KBK 1 \\
\hline 22 & BA & 28,57 & 6,25 & 0,00 & 0,00 & 0,00 & 0,00 & 11,84 & KBK 1 \\
\hline 23 & IL & 42,86 & 0,00 & 0,00 & 25,00 & 0,00 & 0,00 & 18,42 & KBK 1 \\
\hline 24 & CW & 28,57 & 31,25 & 50,00 & 50,00 & 16,67 & 50,00 & 32,89 & KBK 1 \\
\hline 25 & FI & 14,28 & 0,00 & 0,00 & 37,50 & 25,00 & 50,00 & 15,79 & KBK 1 \\
\hline 26 & IA & 71,43 & 31,25 & 25,00 & 25,00 & 8,33 & 0,00 & 39,47 & KBK 1 \\
\hline 27 & JH & 25,00 & 6,25 & 0,00 & 25,00 & 16,67 & 50,00 & 18,42 & KBK 1 \\
\hline
\end{tabular}

$$
\begin{aligned}
& \text { Keterangan } \\
& 1=\text { Interpretasi } \\
& 2=\text { Analisis } \\
& 3=\text { Evaluasi } \\
& 4=\text { Inferensi } \\
& 5=\text { Eksplikasi } \\
& 6=\text { Regulasi Diri }
\end{aligned}
$$

KBK 1= Keterampilan Berpikir Kritis Kategori "Rendah"

KBK 2 = Keterampilan Berpikir Kritis Kategori "Sedang"

KBK 3 = Keterampilan Berpikir Kritis Kategori "Tinggi"

KBK $4=$ Keterampilan Berpikir Kritis Kategori "Sangat Tinggi"

Berdasarkan Tabel 6, 7, dan 8 diperoleh data frekuensi subjek setiap kategori KBK. Untuk keterampilan berpikir kritis kategori sedang (KBK 2) sebanyak tujuh orang (25,92\%), keterampilan berpikir kritis kategori rendah (KBK 1) berjumlah 20 orang (74,07\%), tidak ada siswa yang termasuk ke dalam kelompok KBK 3 dan KBK 4 secara keseluruhan, namun ada beberapa siswa berkategori KBK 3 dan KBK 4 untuk indikator tertentu dari keenam indikator tersebut.

Dari hasil tes diagnosis didapatkan bahwa secara keseluruhan ada tujuh orang siswa $25,92 \%$ berada pada kategori sedang (KBK 2) dan 20 orang siswa 74,07\% berada pada kategori rendah (KBK 1) untuk setiap kemampuannya, siswa berkemampuan tinggi sebesar 36,84\% berada pada kategori rendah (KBK 1), siswa berkemampuan sedang sebesar $34,50 \%$ berada pada kategori rendah (KBK 1), dan siswa berkemampuan rendah $22,80 \%$ berada pada kategori rendah (KBK 1) dengan demikian keterampilan berpikir kritis siswa berada pada kategori rendah dengan persentase rata-rata ketercapaian aktivitas berpikir kritis sebesar 31,38\% dengan persentase ketercapaian setiap indikator secara keseluruhan yaitu $51,58 \%$ pada indikator interpretasi, $18,75 \%$ pada indikator analisis, $13,87 \%$ pada indikator evaluasi, $31,48 \%$ pada indikator inferensi, $14,19 \%$ pada indikator eksplikasi, dan $26,85 \%$ pada indikator regulasi diri. Selanjutnya untuk meyakinkan peneliti maka dilakukan wawancara pada setiap perwakilan per kemampuan, hasil yang didapatkan adalah untuk materi Impuls dan Momentum ternyata belum sepenuhnya di pelajari ada kelas yang baru tiga kali pertemuan, ada yang baru empat kali pertemuan, bahkan ada pada saat tes diagnosis dilakukan baru beberapa kali pertemuan.

Berpikir kritis merupakan salah satu keterampilan berpikir tingkat tinggi. Keterampilan Berpikir Kritis (KBK) tidak bisa diperoleh secara singkat melainkan harus dilatihkan (Haryandi, dkk, 2019). Pembelajaran fisika tidak dapat dipisahkan dari telaah 
teori melalui buku-buku sumber dan pembuktian teori melalui praktikum di laboratorium. Memiliki fasilitas penunjang dan laboratorium yang terstandarisasi untuk praktikum merupakan suatu keniscayaan bagi institusi pendidikan khususnya sekolah menengah atas (SMA). Jika kita mengacu pada keterampilan abad ke-21, KBK salah satu kemampuan berpikir tingkat tinggi dan salah satu kompetensi penting dari 4C (Communication, Collaborative, Critical Thinking, and Problem Solving) yang harus dimiliki peserta didik. KBK bukan sifat yang diturunkan secara genetik melainkan harus dilatihkan melalui proses belajar (Widyaningsih \& Yusuf, 2018).

Berikut beberapa kesulitan siswa dan solusi yang ditawarkan oleh peneliti:

Tabel 9. Kesulitan KBK Siswa dan solusi yang ditawarkan

\begin{tabular}{|c|c|c|c|}
\hline No & Indikator KBK & Kesulitan siswa & Solusi \\
\hline 1. & $\begin{array}{l}\text { Indikator } \\
\text { Interpretasi }\end{array}$ & $\begin{array}{l}\text { kurangnya } \\
\text { pemahaman konsep } \\
\text { fisika }\end{array}$ & $\begin{array}{l}\text { guru harus membantunya dengan } \\
\text { sabar secara pelan-pelan sesuai } \\
\text { dengan daya tangkapnya dan } \\
\text { menambahkan bagian konsep yang } \\
\text { kurang, dan pemanfaatan waktu } \\
\text { karena disini siswa perlu diberikan } \\
\text { waktu khusus untuk membantunya. } \\
\text { Misalnya mengadakan jam } \\
\text { tambahan setelah pulang dari } \\
\text { sekolah. }\end{array}$ \\
\hline 2. & Indikator Analisis & $\begin{array}{l}\text { kurangnya } \\
\text { representasi } \\
\text { penyelesaian soal }\end{array}$ & $\begin{array}{l}\text { mengatasinya dengan meminta siswa } \\
\text { maju kedepan untuk } \\
\text { mengerjakannya secara bersama- } \\
\text { sama jika siswa kesulitan dan } \\
\text { membiasakan siswa untuk mencari } \\
\text { persamaan dengan memberikan } \\
\text { pemahaman konsep yang } \\
\text { terintegrasi, memberikan penjelasan } \\
\text { asal mula persamaan terbentuk dan } \\
\text { menyajikan rumus atau konsep } \\
\text { dalam bentuk yang lebih praktis dan } \\
\text { dibuat menarik agar siswa mau } \\
\text { untuk terus mengolahnya. }\end{array}$ \\
\hline 3. & Indikator Evaluasi & $\begin{array}{l}\text { terbatasnya siswa } \\
\text { menemukan } \\
\text { alternatif } \\
\text { penyelesaian soal, }\end{array}$ & $\begin{array}{l}\text { dapat digali dengan cara } \\
\text { membiasakan diri untuk } \\
\text { mengerjakan soal-soal dengan cara } \\
\text { penyelesaian yang bervariasi, dan } \\
\text { membiasakan siswa untuk } \\
\text { berdiskusi. }\end{array}$ \\
\hline 4. & Indikator Inferensi & $\begin{array}{l}\text { keterbatasan } \\
\text { menghubungkan } \\
\text { substansi antar } \\
\text { materi }\end{array}$ & $\begin{array}{l}\text { guru harus mulai memberikan } \\
\text { latihan kepada siswa yang secara } \\
\text { lebih spesifik mengenai materi fisika } \\
\text { yang kejadiannya secara akrab } \\
\text { dijumpai siswa dalam kehidupan } \\
\text { sehari-hari, dari sana perlahan-lahan } \\
\text { kemampuan siswa dalam }\end{array}$ \\
\hline
\end{tabular}




\begin{tabular}{|l|l|l|l|}
\hline No & Indikator KBK & Kesulitan siswa & \multicolumn{1}{|c|}{ Solusi } \\
\hline & & & $\begin{array}{l}\text { mengaitkan konsep dengan } \\
\text { perhitungan dapat } \\
\text { terwujud sehingga siswa memuliki } \\
\text { kemampuan yang handal dalam } \\
\text { menyimpulkan materi. }\end{array}$ \\
\hline 5. & Indikator Eksplikasi & $\begin{array}{l}\text { Siswa kesulitan } \\
\text { dalam menarik } \\
\text { sebuah kesimpulan }\end{array}$ & $\begin{array}{l}\text { siswa harus dilatih berpikir secara } \\
\text { deduktif maupun induktif. Adakan } \\
\text { diskusi kelas dengan memberikan } \\
\text { tugas portofolio atau melakukan } \\
\text { percobaan yang dilakukan dengan } \\
\text { metode ilmiah }\end{array}$ \\
\hline 6. & $\begin{array}{l}\text { Indikator Regulasi } \\
\text { Diri }\end{array}$ & $\begin{array}{l}\text { asal-asalan dalam } \\
\text { mengerjakan soal }\end{array}$ & $\begin{array}{l}\text { memberikan tugas khusus dengan } \\
\text { sistem penambahan poin jika tugas } \\
\text { yang dikerjakan benar dan tepat, dan } \\
\text { pengurangan poin jika tugas yang } \\
\text { diberikan tidak diselesaikan atau } \\
\text { diselesaikan dengan asal-asalan. }\end{array}$ \\
\hline
\end{tabular}

Hasil penelitian Arini \& Juliadi (2018) menunjukkan beberapa penyelesaian masalah yang untuk Mengatasi Kesulitan Pencapaian KBK adalah sebagai berikut: 1) indikator interpretasi, guru harus membantu siswa dengan sabar secara bertahap sesuai dengan daya tangkapnya dan memberikan tambahan pada bagian konsep yang kurang, 2) indikator analisis, dapat dibantu dengan membiasakan siswa untuk mencari persamaan dengan memberikan pemahaman konsep yang terintegrasi, 3) indikator evaluasi, membiasakan diri untuk mengerjakan soal-soal dengan cara penyelesaian yang bervariasi, 4) indikator inferensi, memberikan latihan kepada siswa secara lebih spesifik mengenai materi fisika yang kejadiannya sering dijumpai siswa dalam kehidupan sehari-hari, 5) indikator eksplikasi, melatih keterampilan berpikir secara deduktif maupun induktif dengan mengadakan diskusi kelas, memberikan tugas portofolio atau melakukan percobaan yang dilakukan dengan metode ilmiah, dan 6) indikator regulasi diri, memberikan tugas khusus dengan sistem penambahan poin jika tugas yang dikerjakan benar dan tepat.

\section{SIMPULAN}

Berdasarkan hasil analisis data penelitian tentang keterampilan berpikir kritis siswa pada materi Impuls dan Momentum di kelas X.MIA SMA Negeri 1 Muara Beliti, peneliti menyimpulkan bahwa:

1. Berdasarkan hasil diagnosis keterampilan berpikir kritis siswa pada materi Impuls dan Momentum siswa kelas X.MIA SMA Negeri 1 Muara Beliti didapatkan bahwa setiap kemampuan, siswa berkemampuan tinggi sebesar 36,84\% berada pada kategori rendah (KBK 1), siswa berkemampuan sedang sebesar 34,50\% berada pada kategori rendah (KBK 1), dan siswa berkemampuan rendah $22,80 \%$ berada pada kategori rendah (KBK 1) dengan demikian keterampilan berpikir kritis siswa berada pada kategori rendah dengan persentase rata-rata ketercapaian aktivitas berpikir kritis sebesar $31,38 \%$ dengan persentase ketercapaian setiap indikator secara keseluruhan yaitu $51,58 \%$ pada indikator interpretasi, $18,75 \%$ pada indikator analisis, $13,87 \%$ pada indikator evaluasi, 31,48\% pada indikator inferensi, 14,19\% pada indikator eksplikasi, 
dan $26,85 \%$ pada indikator regulasi diri. Jika digolongkan berdasarkan tingkatan keterampilan berpikir kritis siswa, persentase ketercapaian rata-rata siswa pada setiap kelompok adalah 52,63\% untuk kelompok KBK 2 sehingga tergolong dalam kategori keterampilan berpikir kritis sedang, dan 23,94\% untuk kelompok KBK 1 sehingga tergolong dalam kategori kemampuan berpikir kritis rendah, dengan jumlah siswa pada kelompok kelompok KBK 2 sebanyak tujuh orang $(25,92 \%)$, dan kelompok KBK 1 sebanyak 20 orang $(74,07 \%)$.

2. Berdasarkan hasil wawancara yang dilakukan peneliti, dapat diketahui bahwa kesulitan siswa dalam mencapai indikator-indikator keterampilan berpikir kritis adalah sebagai berikut:

a. Indikator interpretasi, terletak pada kemampuan sebagian besar siswa dalam memahami materi Impuls yang kurang baik, ada sebagian siswa yang baru mempelajari materi Impuls dan Momentum pada saat tes diagnosis KBK di laksanakan.

b. Indikator analisis, terletak pada kurangnya penyampaian mengenai keterkaitan antara persamaan-persamaan, model matematis dari penyelesaian dengan konsepkonsep yang terkait dengan materi Impuls dan Momentum penggunaan simbolsimbol dalam fisika .

c. Indikator evaluasi, terletak pada kurangnya kemampuan siswa dalam melakukan operasi perhitungan dan menentukan strategi yang tepat dalam menyelesaikan soal, sehingga untuk KBK 1, semua siswa tidak dapat memenuhi indikator evaluasi selain itu juga materi impuls dan momentum baru pengenalan saja belum secara mendalam.

d. Indikator inferensi, terletak pada keterampilan siswa yang lemah dalam menghubungkan suatu permasalahan dengan solusi yang didapatkan.

e. Indikator eksplikasi, terletak pada keterampilan siswa yang tidak dapat melakukan dan bingung untuk penarikan kesimpulan.

f. Indikator regulasi diri, terletak pada kurangnya daya juang siswa untuk menyelesaikan soal ketika menemukan hambatan dalam mengidentifikasi informasi yang disampaikan dengan pertanyaan yang diselesaikan, sehingga jika menemukan soal yang dianggap mereka tidak bisa mengerjakan maka tidak di kerjakan sama sekali.

3. Solusi yang dapat diberikan untuk mengatasi kesulitan siswa dalam mencapai indikator-indikator kemampuan berpikir kritis yaitu:

a. Indikator interpretasi, guru harus membantu siswa dengan sabar secara pelan-pelan sesuai dengan daya tangkapnya dan menambahkan bagian konsep yang kurang.

b. Indikator analisis, dapat dibantu dengan membiasakan siswa untuk mencari persamaan dengan memberikan pemahaman konsep yang terintegrasi dan diiringi dengan kebiasaan siswa mengerjakan soal-soal.

c. Indikator evaluasi, membiasakan diri untuk mengerjakan soal-soal dengan cara penyelesaian yang bervariasi.

d. Indikator inferensi, memberikan latihan kepada siswa secara lebih spesifik mengenai materi fisika yang kejadiannya akrab dijumpai siswa dalam kehidupan sehari-hari.

e. Indikator eksplikasi, melatih keterampilan berpikir secara deduktif maupun induktif dengan mengadakan diskusi kelas, memberikan tugas portofolio atau melakukan percobaan yang dilakukan dengan metode ilmiah. 
f. Indikator regulasi diri, memberikan tugas khusus dengan sistem penambahan poin jika tugas yang dikerjakan benar dan tepat, dan pengurangan poin jika tugas yang diberikan tidak diselesaikan.

\section{SARAN}

1. Siswa, dalam belajar fisika yang terpenting adalah memahami konsep dari memahami konsep tersebut akan memudahkan dalam memahami perumusan matematikanya, untuk itu hendaknya ketika belajar untuk lebih memahami konsep secara mendalam terlebih dahulu tapi bukan berarti harus meninggalkan bentuk matematikannya hanya mengubah pola belajar dan lebih sering mengerjakan soal-soal untuk latihan.

2. Guru, hendaknya untuk selalu membuat variasi dalam mengajar dan selalu memberikan contoh nyata dalam kehidupan keseharian siswa bila perlu hadirkan contoh tersebut di dalam kelas sehinga pikiran siswa akan lebih terbuka dan meluas dalam memahami konsep fisika yang ada di dalam kehidupan mereka alam proses pembelajaran cukup sebagai fasilitator dan hendaknya memberikan jam tambahan setelah pulang sekolah atau perbanyakkan lagi pekerjaan rumah agar siswa ada tanggung jawabnya pada saat mata pelajaran fisika.

3. Penelitian selanjutnya, penelitian tentang keterampilan berpikir kritis siswa telah banyak dilakukan, untuk itu peneliti rekomendasikan untuk menambahkan perlakuan dengan menggunakan model pembelajaran, misalnya model pembelajaran Problem Based Learning (PBL) atau model pembelajaran kontekstual.

\section{DAFTAR PUSTAKA}

Arikunto, S. (2010). prosedur penelitian suatu pendekatan praktik. Jakarta: PT. Rineka Cipta.

Arikunto, S. (2013). Manajemen Penelitian. Bandung: Rineka Cipta.

Ariani, T. (2017). Pembelajaran Kooperatif Tipe Team Assisted Individualization (TAI): Dampak Terhadap Hasil Belajar Fisika Siswa. Jurnal Ilmiah Pendidikan Fisika Al-BiRuNi, 6(2), 169-177.

Arini, W., \& Juliadi, F. (2018). Analisis kemampuan berpikir kritis pada mata pelajaran fisika untuk pokok bahasan Vektor siswa kelas X SMA Negeri 4 Lubuklinggau, Sumatera Selatan. Berkala Fisika Indonesia, 10(1), 1-11.

Desmita. (2012). Psikologi perkembangan peserta didik. Bandung: PT Remaja Rosdakarya

Fatmawati, H. (2014). Mardiyana, \& Triyanto.(2014). Analisis berpikir kritis siswa dalam pemecahan masalah matematika berdasarkan polya pada pokok bahasan persamaan kuadrat (penelitian pada siswa kelas X SMK Muhammadiyah 1 Sragen tahun pelajaran 2013/2014). Jurnal Elektronik Pembelajaran Matematika, 2(9), 911-922.

Fisher. A. (2008). Berpikir kritis sebuah pengantar. Jakarta: Erlangga

Fithriyah. (2016). Analisis Kemampuan Berpikir Kritis Siswa Kelas IX-D SMPN 17 Malang. Paper dipresentasikan di Konferensi Nasional Penelitian Matematika dan pembelajarannya (KNPMP I) Universitas Muhammadiyah Surakarta, Surakarta.

Haryani, D. (2012). Membentuk siswa berpikir kritis melalui pembelajaran matematika. Yogyakarta: prosiding.

Haryandi, S., Misbah, M., Mastuang, M., Dewantara, D., \& Mahtari, S. (2019). Analysis of Students' Critical Thinking Skills on Solid Material Elasticity. Kasuari: Physics Education Journal (KPEJ), 2(2), 89-94. 
Karim, N. (2015). Kemampuan berpikir kritis siswa dalam pembelajaran matematika dengan menggunakan model JUCAMA di sekolah menengah pertama. EDUMAT Jurnal Pendidikan Matematika, 3(1), 92-104.

Lestari. S.W. (2016.) Analisis berpikir kritis siswa dalam pemecahan masalah matematika pada pokok bahasan himpunan ditinjau dari tipe kepribadian ekstrovert dan introvert siswa kelas VII SMPN 2 Sumber Cirebon. Skripsi tidak diterbitkan. Semarang: fakultas sains UIN Walisongo.

Misbah, M., Mahtari, S., Wati, M., \& Harto, M. (2018). Analysis of Students' Critical Thinking Skills in Dynamic Electrical Material. Kasuari: Physics Education Journal (KPEJ), 1(2), 103-110.

Patmawati, H. (2011). Analisis keterampilan berpikir kritis siswa pada pembelajaran larutan elektrolit dan nonelektrolit dengan metode praktikum kelas X.5 SMA Negeri 3 Kota Tasikmalaya. Skripsi tidak diterbitkan. Jakarta: Jurusan MIPA Fakultas Ilmu Tarbiyah Dan Keguruan Universitas Islam Negeri Syarif Hidayatullah..

Purwanto, N. (2010). Prinsip-prinsip dan teknik evaluasi pengajaran. Bandung: Remaja Rosdakarya.

Ritdamaya, D. (2015). Profil keterampilan berpikir kritis siswa sekolah menengah atas dalam materi suhu dan kalor menggunakan instrumen tes berpikir kritis Ennis. Proceeding Seminar Nasional Fisika dan Aplikasinya.

Sugiyono. (2009). Memahami Penelitian Kualitatif. Bandung: Alfabeta.

Sugiyono. (2010). Metode Penelitian Kuantitatif, Kualitatif dan R\&D. Bandung: Alfabeta.

Sukmadinata. (2015). Metode Penelitian Pendidikan. Bandung: Rosdakarya.

Widyaningsih, S. W., \& Yusuf, I. (2018). Project Based Learning Model based on Simple Teaching Tools and Critical Thinking Skills. Kasuari: Physics Education Journal (KPEJ), 1(1), 12-21.

Yati, N., Retni, S. B., \& Afreni, H. (2015). Analisis kemampuan berpikir kritis siswa dalam memecahkan soal pada materi virus di SMA Negeri 3 kota Jambi. Jurnal FKIP Biologi, 1-13. 